\title{
Genes of wheat resistant to leaf rust (Puccinia triticina) in Siberia and Far East in 2020 are the basis for determining the breeding strategy for stress resistance
}

\author{
Piskarev V.V. ${ }^{1 *}$, Sochalova L.P. ${ }^{1}$, Morozova E.V. ${ }^{1}$, Aparina V.A. ${ }^{1}$, Boyko N.I. ${ }^{1}$, \\ Sukhomlinov V.Yu. ${ }^{1}$, Poteshkina A.A. ${ }^{1}$, Aseeva T.A. ${ }^{2}$, Zenkina K.V. ${ }^{2}$ \\ ${ }^{1}$ Siberian Research Institute of Plant Production and Breeding - Branch of the Institute of Cytology and \\ Genetics, SB RAS, Novosibirsk, Russia \\ ${ }^{2}$ Khabarovsk Federal Research Center of the Far Eastern Branch of the Russian Academy of Sciences - \\ Far Eastern Agricultural Research Institute, Khabarovsk, Russia \\ * email: piskaryov_v@mail.ru
}

Creating disease-resistant cultivars is a highly effective and environmentally friendly way to protect crops from biotic stress. The population of Puccinia triticina evolves dependently with the host plant in time and space, resulting in a change in its genetic structure. Mutations, genetic recombinations, and spore migrations are the main factors of fungal variability. Leaf rust samples were collected in 2020 on the territory of Western Siberia (18 locations), Eastern Siberia (3), and Far East (1) to identify differences in the genetic structure of the populations located on the territory. A sample from the Far East was combined with samples from Eastern Siberia when describing the evaluation results. The population structure was studied in laboratory conditions on the leaf segments of isogenic Thatcher lines carrying resistance genes $(\operatorname{Lr} 1, \operatorname{Lr} 2 a, \operatorname{Lr} 2 c, \operatorname{Lr} 3 a, \operatorname{Lr} 9, \operatorname{Lr} 16$, Lr26, Lr3ka, Lr11, Lr17, Lr30, Lr19, Lr20, Lr14a, Lr18, Lr2b, Lr3bg, Lr14b, Lr15, Lr41, Lr45, Lr47) and varieties - Agent (Lr24) Tulaykovskaya 10 (Lr6Agi2), Tulaykovskaya 105 (Lr6Agil), CS2A/2M (Lr28), Pavon F76 (Lr47) and Chelyaba 75 (LrSp2). All samples (18-Western and 4 - Eastern) were virulent to the genes Lr1, Lr2a, Lr30 and Lr2b (damage - 3 points) and avirulent - Lr19, Lr41, Lr47, Lr24, Lr28, Lr6Agi1, Lr6Agi2 and LrSp2 (damage - 0-2 points). The virulence genes for $\operatorname{Lr} 2 k, \operatorname{Lr} 3 a$, Lr16, and $\operatorname{Lrll}$ were found in all samples from Eastern, as well as in 17, 16, 17, and 14 samples from Western Siberia respectively. The virulence gene to $\operatorname{Lr} 9$ was detected in 2 samples from the Altai region and one from the Kuibyshev district of the Novosibirsk region, the rest did not contain them. The Thatcher Lr26 line was affected in $50 \%$ of cases by both samples from Eastern and Western Siberia. Virulence to the Lr45 gene was very rare (a sample from the Suzunsky district of the Novosibirsk region and a sample from the Krasnoyarsk region). Virulence to the $L r 20$ gene was more common in Western Siberia (14 samples) than in Eastern Siberia (1 sample from the Krasnoyarsk region). Thatcher lines with the remaining resistance genes ( $L r 3 k a, L r 3 k g, L r 14 a, L r 14 b$, Lr15, Lr18) were characterized by polymorphic damage in both Western Siberia and Eastern. It should be noted that the Agent variety was damaged by the spores of two samples from the Omsk region and one from the Kuibyshev district (2 points resistance), which later allowed us to isolate and multiply 4 clones that damaged varieties with resistance determined by this gene (KWS Akvilon, Agent, Quintus, Cunningham, etc.) by 3-4 points (susceptibility).

Acknowledgments: The reported study was funded by RFBR, project number 20-01600093. 